\title{
Anti-Inflammatory Compounds of Plant Origin. Part I. Action on Arachidonic Acid Pathway, Nitric Oxide and Nuclear Factor $\kappa \mathrm{B}$ (NF- $\mathrm{kB})$
}

João B. Calixto

Michel F. Otuki ${ }^{1}$

Adair R.S. Santos ${ }^{2}$

\section{Abstract}

Over the last 10 years, a significant body of evidence has emerged indicating that chemically diverse classes of naturally-occurring substances derived from higher plants are of potential interest for therapeutic interventions in several inflammatory diseases. Part I of this review article focuses on our current knowledge of the mechanisms by which a large range of plant-derived constituents interfere with three relevant targets involved in the inflammatory process, namely arachidonic acid metabolite pathways, nitric oxide and $\mathrm{NF}-\kappa \mathrm{B}$, and discusses their potential therapeutic use in the management of relevant inflammatory diseases.

\section{Key words}

Medicinal plants · plant constituents · inflammation

\section{Abbreviations}

AP-1: $\quad$ activator protein-1

CAPE: caffeic acid phenethyl ester
COX: cyclooxygenase

ELAM-1: endothelial-leukocyte adhesion molecule-1

ICAM-1: intercellular adhesion molecule-1

IL: interleukin

iNOS: inducible nitric oxide synthase

LO: lipoxygenase

LPS: lipopolysaccharide

LT: leukotriene

MPO: myeloperoxidase

NF- $\kappa \mathrm{B}$ : nuclear factor kappa B

NO: nitric oxide

$\mathrm{PGE}_{2}$ : prostaglandin $\mathrm{E}_{2}$

$\mathrm{TXA}_{2}$ : $\quad$ thromboxane $\mathrm{A}_{2}$

PLA $_{2}$ : $\quad$ phospholipase $A_{2}$

PKC: $\quad$ protein kinase $C$

PMA/TPA: phorbol myristate acetate

TGF- $\beta 1$ : transforming growth factor- $\beta 1$

TNF- $\alpha$ : tumour necrosis factor

CAM-1: $\quad$ vascular cell adhesion molecule-1 Brazil · Phone: +55-48-3319491·Fax: +55-48-2224164·E-mail: calixto@farmaco.ufsc.br or calixto3@terra.com.br

Funding

Michel Otuki is a PhD student in Pharmacology and he thanks Coordenação de Aperfeiçoamento de Pessoal de

Nível Superior (CAPES) for fellowship support. The studies from our group were supported by the Conselho Nacional de Desenvolvimento Científico e Tecnológico (CNPq), Financiadora de Estudos e Projetos (FINEP) and by Programa de Apoio aos Grupos de Excelência (PRONEX), Brazil.

Received March 21, 2003 · Accepted June 19, 2003 


\section{Introduction}

Inflammation is the response of the organism to invasion by a foreign body, such as bacteria, parasites and viruses. In this context, the inflammatory response is a critical protective reaction to irritation, injury, or infection, characterised by redness, heat, swelling, loss of function and pain [1]. Redness and heat result from an increase in blood flow, swelling is associated with increased vascular permeability, and pain is the consequence of activation and sensitisation of primary afferent nerve fibres [1]. Under normal conditions, these changes in inflamed tissue serve to isolate the effects of the insult and thereby limit the threat to the organism [1].

Our understanding of the molecular and cellular mechanisms involved in the inflammatory process has increased dramatically in recent decades and this has permitted the discovery of many promising targets for the development of new drugs to treat chronic inflammatory diseases, such as rheumatoid arthritis, allergy, asthma, inflammatory bowel disease, and others. A great number of inflammatory mediators including kinins, platelet-activating factor, prostaglandins, leukotrienes, amines, purines, cytokines, chemokines and adhesion molecules, has been found to act on specific targets (e.g., the microvasculature), leading to the local release of other mediators from leukocytes (e.g., mast cells and basophils) and the further attraction of leukocytes, such as neutrophils, to the site of inflammation [1].

A continuous flow of new findings from immunohistochemical, biochemical, molecular and functional animal models, together with clinical studies, has greatly increased the interest in the study of the mechanisms that underlie the inflammatory process. In recent years, roles have been identified for several inflammatory cells and for a large number of inflammatory mediators in important pathologies not previously known to be linked to inflammation, such as Alzheimer's disease and cardiovascular disorders including atherosclerosis, as well as cancer (see for recent review [2], [3]). Such findings have significantly increased the importance of, first, understanding the cellular and molecular mechanisms forming the basis of the inflammatory process and, second, identifying new targets for the development of innovative and safe therapeutic strategies to manage inflammatory diseases.

Natural products, including those derived from higher plants have, over the years contributed greatly to the development of modern therapeutic drugs. Most plant-derived secondary metabolites are known to interfere directly or indirectly with the following molecules and/or mechanisms: various inflammatory mediators (e.g. arachidonic acid metabolites, peptides, cytokines, excitatory amino acids, etc.), the production and/or action of second messengers (such as cGMP, cAMP, various protein kinases, and calcium, among others), the expression of transcription factors such as AP$1, N F-\kappa B$, and proto-oncogenes ( $c$-jun, $c-f o s$, and $c-m y c)$, and the expression of key pro-inflammatory molecules such as inducible NO synthase (iNOS), cyclooxygenase (COX-2), cytokines (IL-1 $\beta$, TNF- $\alpha$, etc.), neuropeptides and proteases.

In the first part of this review we highlight recent contributions of naturally occurring substances from higher plants acting on the arachidonic acid pathway, nitric oxide and the transcription factor NF- $\kappa \mathrm{B}$, to the development of new drugs to treat acute and chronic inflammatory processes.

\section{Prostanoid Inhibitors Derived from Plants}

Curcumin (1) is a naturally-occurring yellow pigment present in the rhizomes of the plant Curcuma longa L. (Zingiberaceae), found in southern Asia. Apart from its use as a colouring and flavouring spice in foods, curcumin has also been widely used in the management of distinct inflammatory disorders and wound healing. It has been reported that curcumin possesses antioxidant, hepatoprotective and antitumoural actions [4], [5], [6], [7], [8], [9], [10], [11], [12], [13]. More recently, there have been a number of pre-clinical reports suggesting that curcumin exerts an anti-inflammatory action in models of atherosclerosis, Alzheimer's disease, arthritis and pancreatitis [6], [7], [8], [9], [10]. Several mechanisms have been proposed to explain the reported anti-inflammatory action of curcumin, including the inhibition of macrophage activation, and inhibition of lipoxygenase (LO) and cyclooxygenase 2 (COX-2), metabolite production via arachidonic acid pathways [11], [12], [13], [14], [15]. For a recent review of the anti-inflammatory action of curcumin see [6], [16].

Resveratrol (2) is a phytoalexin polyphenol present in grape skins and, consequently, red wines, and most other plants, and it is known to have a wide range of biological actions, including anti-allergic, anti-inflammatory, antioxidant, anticarcinogenic and antiplatelet activities [17], [18], [19], [20], [21]. In relation to its anti-inflammatory actions, resveratrol has been found to inhibit both COX-1 and COX-2 enzymes and prostanoid product generation via the LO pathway. Furthermore, resveratrol inhibits apoptosis in $\mathrm{K} 562$ cells through a mechanism involving inhibition of both LO and COX activities [22], [23]. Recent molecular studies have revealed that resveratrol acts at a broad range of sites and this seems likely to account for its pharmacological properties. Among other effects, resveratrol causes a pronounced reduction in the $c$-fos and TGF- $\beta 1$ expression in mouse skin stimulated by phorbol myristate acetate (PMA) [24]. Furthermore, resveratrol inhibits COX-2 transcription and activity associated with inhibition of AP-1-mediated gene expression in PMA-treated mammary epithelial cells, by inhibiting signal transduction through protein kinase $\mathrm{C}$ (PKC) [25]. Although the precise mechanisms by which resveratrol exerts its effects are unknown, these findings may explain, at least in part, the basis by which resveratrol exerts its anti-inflammatory actions and its favourable effects in the treatment of cardiovascular diseases and cancer. For a recent review on the anti-inflammatory actions of resveratrol see [17], [18], [26].

Flavonoids are broadly distributed in plants and have been reported to display marked in vitro and in vivo anti-inflammatory properties (see for recent reviews [27], [28]). The flavonoid baicalein (3), isolated from the roots of Scutellaria baicalensis Georgi (Lamiaceae) has been shown to selectively inhibit 5-LO and also $\mathrm{LTC}_{4}\left(\mathrm{IC}_{50}=9.5 \mu \mathrm{M}\right)$ production in rat resident peritoneal macrophages [29]. Oral application of baicalein (but not baicalin and wogonin) reportedly ameliorates several inflammatory symptoms of experimental colitis, such as body-weight loss, low blood 
<smiles>COc1cc(/C=C/C(=O)CC(=O)/C=C/c2ccc(O)c(OC)c2)ccc1O</smiles>

(1) curcumin

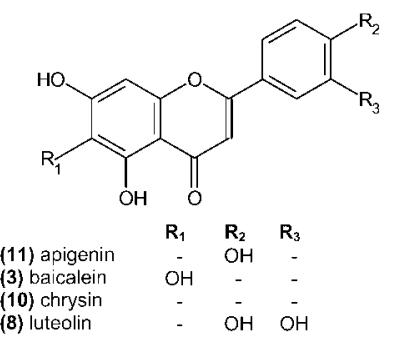<smiles>COc1c(O)cc(O)c2c(=O)cc(-c3ccccc3)oc12</smiles>

haemoglobin content and rectal bleeding [30]. Topical application of baicalin inhibits TPA-induced ear oedema as well as ornithine decarboxylase and myeloperoxidase activity in mouse skin, suggesting its potential as an anti-cancer agent [31]. In addition, the three flavonoids baicalein, baicalin and wogonin exhibit antioedematogenic properties in rats [32]. Furthermore, baicalin (4) inhibits the production of prostaglandin $\mathrm{E}_{2}$ in $\mathrm{C} 6$ rat glioma cells, and leukotriene $\mathrm{B}_{4}\left(\mathrm{LTB}_{4}\right)$ biosynthesis $[29,33]$, while oroxylin $A$ (5), baicalein and wogonin (6) inhibit 12-LO without affecting the levels of cyclooxygenase in human platelets [34].

Another flavonoid compound, cirsiliol (7) isolated from Achillea fragrantissima Forssk. (Asteraceae) has proven to be a potent inhibitor of 5-LO $\left(\mathrm{IC}_{50}=0.1 \mu \mathrm{M}\right)$ in rat basophilic leukaemia cells and in guinea pig peritoneal polymorphonuclear leukocytes [35]. In addition, the oral administration of cirsiliol to mice caused a dose-dependent inhibition of the paw oedema and leukocyte infiltration induced by injection of carrageenan [36]. Other plantderived flavonoids, including luteolin (8) and morin (9), also exhibit moderate inhibition of the rat renal medulla COX-2 activity. There is evidence indicating that the flavones chrysin (10), apigenin (11) and phloretin (12) are effective in preventing COX-2 expression [37] and in inhibiting platelet aggregation [38]. Fiebrich and Koch [39] showed that the three pharmacologically active constituents denoted silymarin, namely, silybin, silydian and silychristin, from Silybum marianum L. (milk thistle) (Asteraceae) also inhibit both LO and COX activity. More recently, it has been reported that these compounds are capable of inhibiting the inflammatory response when assessed in several in vivo models, most probably through the inhibition of COX-2 expression [40], [41]. Likewise, the flavonoids rutin (13), quercetin (14), wogonin,<smiles>Oc1ccc(/C=C/c2cc(O)cc(O)c2)cc1</smiles><smiles>COc1c(O)cc2oc(-c3ccccc3)cc(=O)c2c1O</smiles><smiles>COc1cc2oc(-c3ccccc3)cc(=O)c2c(O)c1O</smiles><smiles>COc1cc2oc(-c3ccc(O)c(O)c3)cc(=O)c2c(O)c1OC</smiles>

apigenin, galanin, morin and naringenin also inhibit COX-2 expression and activity in macrophages [37], [42], [43], [44]. Hamamelitannin (15) and the galloylated proanthocyanidins isolated from Hamamelis virginiana $\mathrm{L}$. (Hamamelidaceae) exhibit pronounced inhibition of 5-LO $\left(\mathrm{IC}_{50}\right.$ values ranging from 1.0 to 18.7 $\mu \mathrm{M})$ [45]. It has been recently reported that ginkgetin, a biflavone from Ginkgo biloba L. (Ginkgoaceae) leaves is effective in inhibiting phospholipase $\mathrm{A}_{2}$ and reduces arthritic inflammation in rat adjuvant-induced arthritis as well as the abdominal constriction caused by acetic acid $\left(\mathrm{ID}_{50}=8.9 \mathrm{mg} / \mathrm{kg}\right)$ [46]. In addition, ginkgetin and the biflavone mixture inhibited croton oil-induced ear skin oedema by down-regulation of COX-2 [47]. The isoflavones tectorigenin and tectoridin (a glycosylated tectorigenin) isolated from the rhizomes of Belamcanda chinensis L. (Iridaceae) inhibit $\mathrm{PGE}_{2}$ production in TPA-stimulated rat peritoneal macrophages [48], [49]. Very recently, Sadik et al. [50] have described the inhibition of 15-lipoxygenase by a series of flavonoids and have confirmed the great potency of luteolin and baicalein.

Sala et al. [51], [52], [53] have isolated several acetophenones from aerial parts of Helichrysum italicum (Roth) G. (Asteraceae) that were found to inhibit arachidonic acid metabolism. 4-Hydroxy-3-(3-methyl-2-butenyl)acetophenone and 4-hydroxy-3(2-hydroxyl-3-isopentenyl)acetophenone caused a concentration-dependent inhibition of $\mathrm{LTB}_{4}$ production in calcium ionophore-stimulated leukocytes with $\mathrm{IC}_{50}$ of 24 and $111 \mu \mathrm{M}$, respectively. Some of these compounds also consistently inhibited myeloperoxidase (MPO) activity and showed in vivo anti-inflammatory activity against carrageenan and $\mathrm{PLA}_{2}$-induced mouse paw oedema [52]. Tiliroside had the higher anti-inflammatory activity of three flavonoids (with gnaphaliin and pinocembrin) 

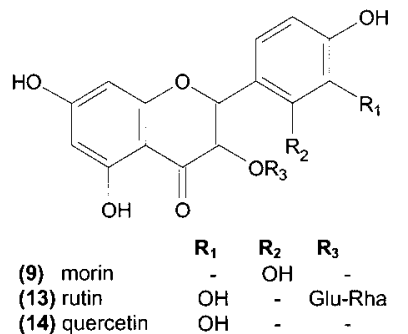

$\begin{array}{llll}\text { (13) rutin } & \mathrm{OH} & - & \mathrm{Glu}-\mathrm{Rh} \\ \text { (14) quercetin } & \mathrm{OH} & - & -\end{array}$

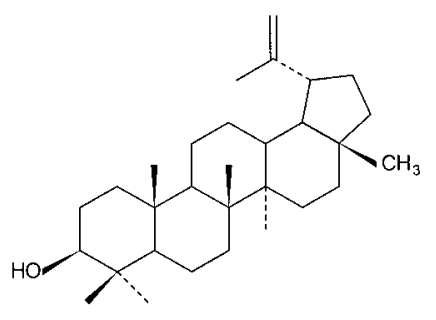

(16) lupeol<smiles>O=C(CCc1ccc(O)cc1)c1c(O)cc(O)cc1O</smiles>

phtoretin

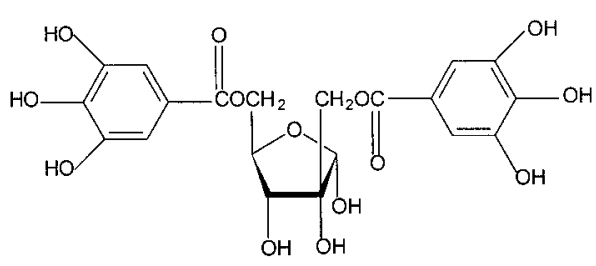

(15) hamamelitannin

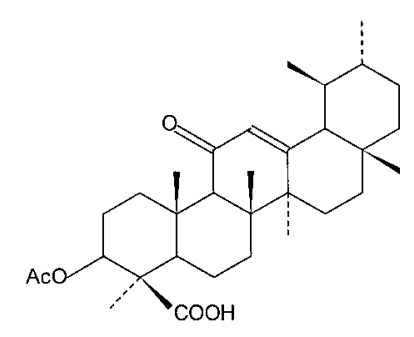

(17) acetyl-11-keto- $\beta-B A$<smiles>O=C(/C=C/c1ccc(O)c(O)c1)OCCc1ccccc1</smiles>

(21) caffeic acid phenethyl ester isolated from $H$. italicum (Roth) G. and tested in several animals, inhibiting the mouse paw oedema induced by $\mathrm{PLA}_{2}\left(\mathrm{ID}_{50}=\right.$ $35.6 \mathrm{mg} / \mathrm{kg}$ ) and the mouse ear inflammation induced by TPA $\left(\mathrm{ID}_{50}=357 \mu \mathrm{g} /\right.$ ear $)$ as well as enzymatic and non-enzymatic lipid peroxidation ( $\mathrm{IC}_{50}=12.6$ and $28 \mu \mathrm{M}$, respectively) [53].

Pentacyclic triterpenes constitute a class of naturally occurring substances that are widely distributed in plants and possess a broad range of biological actions, including pronounced anti-inflammatory effects, as confirmed by in vivo and in vitro experiments. These effects appear to be related to interference with key components of the inflammatory response. As a comprehensive review on the anti-inflammatory actions of pentacyclic triterpenes has been recently published [54], we will focus here only on the more recent and relevant findings regarding this topic.

Topical application of the lupane pentacyclic triterpene lupeol (16) inhibits TPA-induced ear oedema and myeloperoxidase activity in mice. These effects seem likely to involve decreased prostanoid production, because lupeol prevents $\mathrm{PGE}_{2}$ generation in macrophages without affecting the levels of $\mathrm{LTC}_{4}$ [55]. Suh et al. [56] screened more than 80 pentacyclic triterpenes and found that most of them prevented COX-2 and iNOS expression in RAW 264.7 macrophages. It has been recently reported that furanoligularenone, an eremophilane isolated from Ligularia fischeri var. spiciformis (Compositae), inhibits both the production of $\mathrm{PGE}_{2}$ $\left(\mathrm{IC}_{50}=1.93 \mu \mathrm{M}\right)$ and expression of COX-2 in RAW 264.7 stimulated by LPS [57].

The gum resin of Boswellia serrata Roxb. (Burseraceae) is reported to be beneficial in the treatment of patients with chronic colitis. Its positive effects may be, at least in part, related to the presence of the pentacyclic triterpene boswellic acid [58]. Boswellic acid has been found in Boswellia carterii Birdw. (Burseraceae) and it partially but selectively inhibits 5-LO in ionophore-stimulated peritoneal polymorphonuclear leukocytes [59]. Acetyl-11keto- $\beta$-boswellic acid (17) inhibits the 5-LO in rat neutrophils in a non-competitive and specific manner $\left(\mathrm{IC}_{50}=1.5 \mu \mathrm{M}\right)$ [60]. Using several pentacyclic triterpene analogues, Sailer et al. [60] have shown that the inhibition of LO by these compounds depends on the presence of the pentacyclic skeleton.

Avicins (18), a family of triterpenoid saponins isolated from Acacia victoria Bentham (Leguminosae) inhibit the expression of COX-2 through inhibition of NF- $\kappa$ B [61]. In addition, saikosaponins, isolated from Scrophularia scorodonia L. (Scrophulariaceae) and Bupleurum rigidum L. (Apiaceae), as well as two tirucallanetype lanostanoids (masticaienonic acid and masticadienolic acid) and oleanane (morolic acid), from Pistacia terebinthus L. (Anacardiaceae), have anti-inflammatory effects in vivo. Thus, they prevented ear oedema formation caused by PMA and also the synthesis of LO products, especially $\mathrm{LTC}_{4}$ and, to a lesser extent, COX metabolites derived from arachidonic acid [62], [63], [64]. Similarly, platycodin D isolated from the roots of Platycodon grandiflorum A. DC. (Campanulaceae) suppresses $\mathrm{PGE}_{2}$ production and inhibits the induction of COX-2, but not COX-1, in rat peritoneal macrophages [65]. Diaz Lanza et al. [66] have demonstrated that three phenylpropanoids (salidroside and syringin) and lignan (phillyrin), isolated from the leaves of Phillyrea latifolia $\mathrm{L}$. (Oleaceae), are capable of inhibiting production of the COX metabolite $\mathrm{PGE}_{2}\left(\mathrm{IC}_{50}=72.1,35.5\right.$ and $45.6 \mu \mathrm{M}$, respectively) and, to a lesser extent, reducing $\mathrm{TXB}_{2}$ levels $\left(\mathrm{IC}_{50}=154,29.3\right.$ and $168 \mu \mathrm{M}$, respectively); however, coniferin inhibits both $\operatorname{COX}\left(\mathrm{PGE}_{2}\left[\mathrm{IC}_{50}=75.2 \mu \mathrm{M}\right]\right.$ and $\mathrm{TXB}_{2}\left[\mathrm{IC}_{50}=619\right.$ $\mu \mathrm{M}]$ ) and 5-LO metabolites, especially $\mathrm{LTC}_{4}\left(\mathrm{IC}_{50}=63.6 \mu \mathrm{M}\right)$, in calcium-stimulated mouse peritoneal macrophages and human platelets [66]. It has been recently shown that lignans, such as diphyllin acetylapioside, an arylnaphthalene-type, isolated from Haplophyllum hispanicum Spach. (Rutaceae) exhibit topical antiinflammatory activity through inhibition of 5-lipoxygenase [67].

Ursolic acid (19) and the oleanic acid (20) isomers extracted from Plantago major L. (Plantaginaceae), have also been shown to selectively inhibit the COX-2 enzyme, although their mean $\mathrm{IC}_{50}$ values are considerably high (130 and $295 \mu \mathrm{M})$ [68]. Ursolic acid also exhibits anti-inflammatory properties [69], [70]. However, Suh et al. [56] did not find any inhibition of COX-2 by either of the triterpenes. Subbaramaiah et al. [71], in a very interesting and elegant study, explored further the molecular mechanisms 
by which ursolic acid inhibits COX-2 in PMA-treated human mammary and oral epithelial cells, showing also that this is mediated by a cAMP response element in the COX-2 promoter, associated with inhibition of protein kinases [71]. The synthetic oleane triterpene 2-cyano-3,12-dioxoolean-1,9-dien-28-oic acid also inhibits COX-2 expression and shows potent antiproliferative and anti-inflammatory activity [72].

$\beta$-Turmerone and ar-turmerone are sesquiterpenes from Curcuma zedoaria L. (Zingiberaceae) that inhibit LPS-induced $\mathrm{PGE}_{2}$ production in RAW 264.7 cells [73]. It has been demonstrated that several sesquiterpenoids, including ilicic acid and inuviscolide, isolated from Inula viscosa Ait. (Asteraceae) possess anti-inflammatory activity in vivo, being capable of preventing the ear oedema caused by TPA $\left(\mathrm{ID}_{50}=0.65 \mu \mathrm{mol} / \mathrm{ear}\right)$, while also inhibiting the synthesis of $\mathrm{LTB}_{4}\left(\mathrm{IC}_{50}=94 \mu \mathrm{M}\right)$ in rat peritoneal neutrophils [74]. Rosas-Romero et al. [75] have demonstrated that two sesquiterpene lactones, $9 \beta$-hydroxy-atripliciolide 8 - 0 -tiglate and $9 \beta$-hydroxyatripliciolide 8-O-(5'-acetoxytiglate) from Lourteigia ballotaefolia (H.B.K.) (Asteraceae) inhibit the ear oedema caused by croton oil in mice. Likewise, a new iridoid, pendunculariside and agnuside, from the stem bark of Vitex penduncularis (Verbenaceae) showed preferential inhibition of COX-2 $\left(\mathrm{IC}_{50}=0.15\right.$ and $0.026 \mathrm{mg} / \mathrm{mL}$, respectively), while having only a small inhibitory effect on COX1 activity [76].

Several fatty acids extracted from Plantago major L. (Plantaginaceae), including linoleic acid, myristic acid, palmitic acid and steatic acid, have been found to inhibit both COX-1 and COX-2 ( IC $_{50}=3.9$ to $\left.180 \mu \mathrm{M}\right)$ activities. However, they lack selectivity against these enzymes [77]. The phenolic antioxidant substance caffeic acid phenethyl ester (CAPE) (21), a compound produced by honeybees from the gum of various plants, has been shown to possess anti-inflammatory, anticarcinogenic, antimitogenic and immunomodulatory properties. Evidence now indicates that CAPE inhibits the activity of both COX-1 and COX-2 ( IC $_{50}$ of 58 and $82 \mu \mathrm{M}$, respectively) along with COX-2 expression in human oral epithelial cells [78]. When tested in a rat carrageenan air pouch model of inflammation CAPE, administered systemically, caused dose-dependent inhibition of $\mathrm{PGE}_{2}$ formation in the exudate with complete inhibition at $100 \mathrm{mg} / \mathrm{kg}$ (mean $\mathrm{ID}_{50}$ of $23 \mathrm{mg} / \mathrm{kg}$ ). In addition, CAPE markedly reduced the amount of COX-2 in the pouch, while indomethacin, a non-specific COX inhibitor, only inhibited the $\mathrm{PGE}_{2}$ production [79].

There is evidence showing that some phenols, including 5,7,5'trihydroxy-3,6,2',4'-tetramethoxyflavone, scopoletin and centaureidin from Eupatorium buniifolium $\mathrm{H}$. et A. (Asteraceae) [80], as well as some acetylenes from the rhizomes of Atractylodes lancea DC. (Asteraceae), have anti-inflammatory actions. They prevented ear oedema caused by TPA and inhibited COX-1 and 5-LO activities [81]. Danz et al. [82], showed that the alkaloid tryptanthrin from Isatis tinctoria L. (Brassicaceae), reduces inflammation by blocking the production of several metabolites of arachidonic acid $\mathrm{TXB}_{2}$ and 6-ketoPGF ${ }_{1 \infty}$ as well as by decreasing the activity of both COX in monocytes Mac 6 and RAW 264.7 cells. In addition, tryptanthrin also reduces the production of 5-LO metabolites, especially $\mathrm{LTB}_{4}$, in calcium-stimulated human neutrophils [82]. The quinazolinocarboline alkaloid rutaecarpine (22) from Evodia rutaecarpa Bentham (Rutaceae) was reported to inhibit LPS-induced $\mathrm{PGE}_{2}$ production in RAW 264.7 cells [83]. This compound also reduced the rat paw oedema induced by carrageenan and the conversion of exogenous arachidonic acid to $\mathrm{PGE}_{2}$ in $\mathrm{COX}-2$ transfected HEK293 cells. However, rutaecarpine did not change PLA $\mathrm{A}_{2}$ and

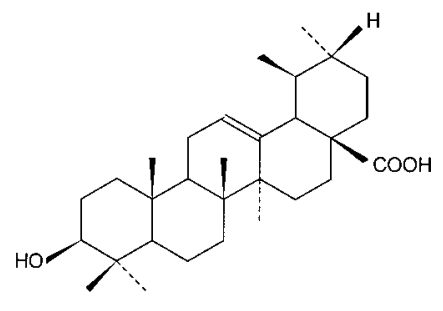

(19) ursolic acid<smiles>COc1cc(CNC(=O)CCCC/C=C/C(C)C)ccc1O</smiles><smiles>CC1=C(O)C(=O)C=C2C1=CC=C1C2(C)CC[C@]2(C)[C@H]3C[C@](C)(C(=O)O)CCC3(C)CC[C@]12C</smiles>

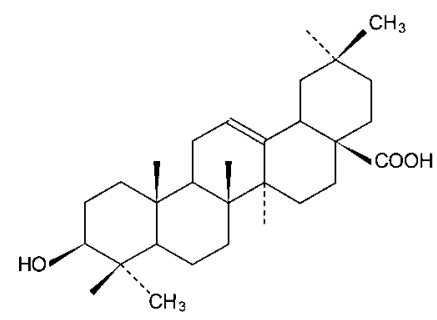

(20) oleanolic acid<smiles>O=c1c2ccccc2nc2n1CCc1c-2[nH]c2ccccc12</smiles>

(22) rutaecarpine<smiles></smiles>

(25) epigallocatechin-3-gallate 
COX-1 activities nor COX-2 expression in bone marrow-derived mast cells [84]. It has been shown that rutaecarpine reduces human platelet aggregation probably by the initial inhibition of phosphoinositide breakdown, followed by inhibition of $\mathrm{TXA}_{2}$ formation as well as $\left[\mathrm{Ca}^{2+}\right]_{\mathrm{i}}$ mobilization [85]. More recently, Sheu et al. [86] have shown that rutaecarpine has an antithrombotic effect in mice against ADP-induced acute pulmonary thrombosis and fluorescein sodium-induced platelet thrombus in mesenteric microvessels, as well as affecting haemostatic bleeding time in rat mesenteric arteries. Furthermore, rutaecarpine exerts vasodilatory and hypotensive effects in the rat by activating the endothelial $\mathrm{Ca}^{2+}$-nitric oxide-cGMP pathway, as well as exerting a minor direct inhibition of membrane $\mathrm{Ca}^{2+}$ channels and intracellular $\mathrm{Ca}^{2+}$ release in vascular smooth muscle cells [87]. Kobayashi et al. [88] described positive inotropic and chronotropic effects elicited by rutaecarpine on the guineapig isolated right atria, via interaction with vanilloid receptors and release of the neuropetide CGRP. Recently, Hu et al. [89], [90], [91] have further extended these observations indicating that cardioprotective, depressor and vasodilator effects of rutaecarpine are associated with stimulation of endogenous CGRP release via activation of vanilloid receptors.

Finally, some standardised plant extracts currently used in most countries for the management of various pathologies are known to interfere with prostanoid synthesis, mainly via inhibition of COX and LO activities. Examples of plants producing such extracts are: Echinacea purpurea L. (Asteraceae), Hamamelis virginiana L. (Hamamelidaceae), Tanacetum vulgare L. (Asteraceae), Urtica dioica L. (Urticaceae), Rheum palmatum L. (Polygonaceae), Arnica montana L. (Asteraceae), Allium sativum L.
(Liliaceae), Heterotheca inuloides Cass. (Asteraceae), Angelica sinensis (Oliv.) Diels (Umbelliferae) and Artemisia species (Asteraceae) [92], [93], [94], [95], [96], [97], (for review see [98]).

\section{Plant-Derived Constituents that Interfere with the Nuclear Transcription Factor кB (NF- кB)}

$\mathrm{NF}-\kappa \mathrm{B}$ is a ubiquitous and well-characterised protein responsible for the regulation of complex phenomena, with a pivotal role in controlling cell signalling in the body under certain physiological and pathological conditions. Among other functions, NF- $\kappa \mathrm{B}$ controls the expression of genes encoding the pro-inflammatory cytokines (e.g., IL-1, IL-2, IL-6, TNF- $\alpha$, etc.), chemokines (e.g., IL-8, MIP-1 $\alpha$, MCP1, RANTES, eotaxin, etc.), adhesion molecules (e.g., ICAM, VCAM, E-selectin), inducible enzymes (COX-2 and iNOS), growth factors, some of the acute phase proteins, and immune receptors, all of which play a critical role in controlling most inflammatory processes (for reviews, see [99], [100]). In unstimulated cells, NF- $\kappa \mathrm{B}$ is present in the cytoplasm as an inactive heterodimer composed of two sub-units, p50 and p65 (also called relA). The heterodimer is complexed with an inhibitory protein $\mathrm{I} \kappa \mathrm{B}-\alpha$, preventing it from moving into the cell nucleus. When activated by certain inflammatory agents, specific protein kinases phosphorylate the I $\kappa \mathrm{B}-\alpha$ protein, causing its rapid degradation, and NF- $\kappa \mathrm{B}$ becomes dissociated from I $\kappa \mathrm{B}-\alpha$. Phosphorylated $\mathrm{I} \kappa \mathrm{B}$ is then rapidly degraded by the proteasome, leading to the translation of NF- $\kappa B$ to the nucleus, where it binds to specific DNA sequences present in the promoters of numerous target genes [99], [100].

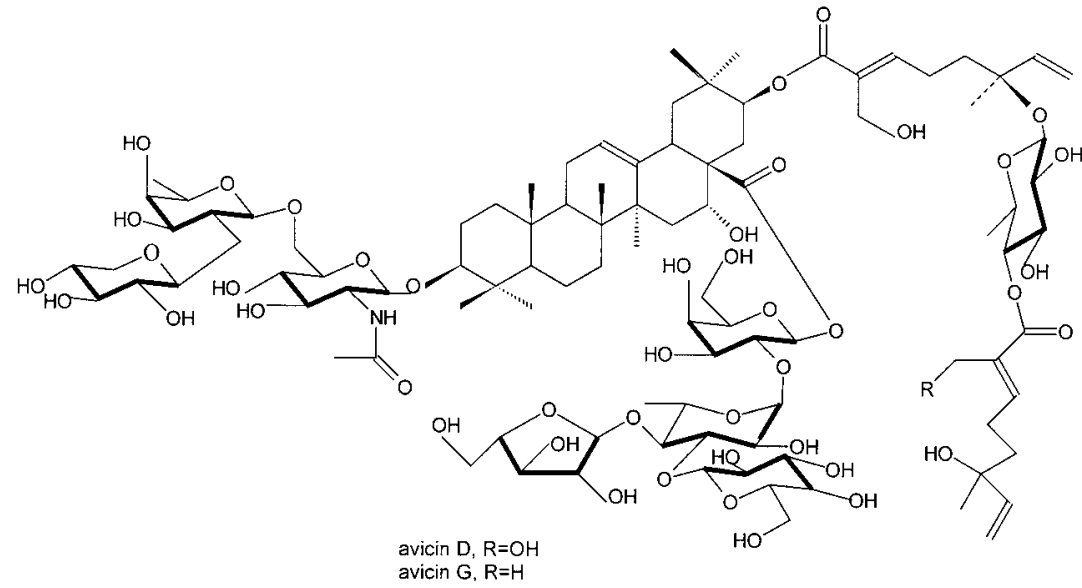

(18) avicins

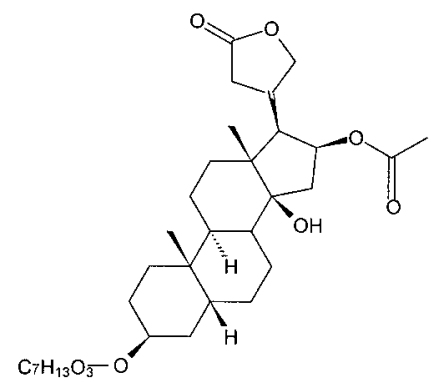

(27) oleandrin

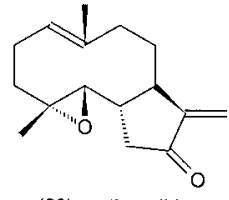

(23) parthenolide

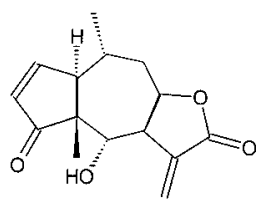

(24) helenalin 
Since NF- $\kappa B$ represents an important and very attractive therapeutic target for drugs to treat many inflammatory diseases, including arthritis, asthma, and the auto-immune diseases, most attention has been paid in the last decade to the identification of compounds that selectively interfere with this pathway. More recently, a great number of plant-derived substances has been evaluated as possible inhibitors of the NF- $\kappa$ B pathway. Interesting and comprehensive reviews published recently discuss in detail some specific groups of naturally-occurring substances of plant origin capable of interfering with NF- $\kappa B$ [101], [102]. Thus, we will discuss in this section distinct classes of plant-derived compounds that form part of this group, emphasising recently published data.

The NF- $\kappa$ B pathway is affected by several distinct classes of plant-derived compounds including: curcumin (1), pathenolide (23), ergolide, $2 \beta, 5$-epoxy-5,10-dihydroxy-6 $\alpha$-angeloyloxy- $9 \beta$ isobutyloxy-germacran-8 $\alpha, 12$-olide, andalusol, ent-kaur-16ene-19-oic acid, kamebanin, kamebacetal A, kamebakaurin, exvisanin A, hypoestoxide, resveratrol (2), helenalin (24), pristimerin, epigallocatechin gallate (25), avicin (18), quercetin (14), capsaicin (26), silymarin, the diterpene hypostoxide, oleandrin (27), vesnarinone and caffeic acid phenethyl ester (CAPE) (21). The majority of these compounds are anti-oxidants and act by blocking the protein kinase-mediated $\mathrm{I} \kappa \mathrm{B}$ degradation, thereby preventing NF- $\kappa \mathrm{B}$ activation.

Recently, Gukovsky et al. [10] reported that curcumin ameliorates ethanol- and non-ethanol-induced experimental pancreatitis (causing pronounced inhibition of the serum amylase and lipase increase, reduction of neutrophil influx and inhibition of intrapancreatic trypsin activation). They found that the inhibition of NF- $\kappa \mathrm{B}$ and $\mathrm{AP}-1$, another important pro-inflammatory transcription factor, is largely responsible for this effect. The authors concluded that curcumin, which is currently in clinical trials for cancer prevention, has therapeutic potential for the management of pancreatitis. Jobin et al. [103] demonstrated that curcumin blocks cytokine-induced pro-inflammatory gene expression in intestinal epithelial cells by inhibition of the signal leading to IKK activation, subsequent $\mathrm{I} \kappa \mathrm{B}$ phosphorylation/degradation, and $\mathrm{NF}-\kappa \mathrm{B}$ activation. Furthermore, evidence also indicates that curcumin is able to inhibit the $I \kappa B$ kinase 1 and $I \kappa B$ kinase 2 activities induced after stimulation with LPS [104]. Very recently, Ukil et al. [105] shown that curcumin exerts beneficial effects on 2,4,6-trinitrobenzenesulphonic acid-induced colitis in mice, a model for inflammatory bowel disease. The anti-inflammatory effects of curcumin are associated with an inhibition of up-regulation of the pro-inflammatory Th1 cytokine response leading to the suppression of iNOS and attenuation of the recruitment of neutrophils and lipid peroxidation that in turn reduce tissue injury. The authors suggested that curcumin may be useful in the management of human inflammatory bowel disease [105].

Recent results suggest that silymarin inhibits nitric oxide production and iNOS gene expression by inhibiting NF- $\kappa \mathrm{B} /$ Rel activation in RAW 264.7 macrophages. Furthermore, the radicalscavenging activity of silymarin may explain its inhibitory effect on NF- $\kappa \mathrm{B} /$ Rel activation [106]. In a recent study, Dhanalakshmi et al. [107] revealed that silibinin (a component of silymarin) effectively inhibits constitutive activation of NF- $\kappa$ B in DU145 human prostate adenocarcinoma cells. The flavonoid apigenin (11) was shown to down-modulate the constitutive expression of NF- $\kappa \mathrm{B} /$ p65 in the human prostate adenocarcinoma cell line LNCaP. Such data suggest that apigenin has strong potential for the development of agents to prevent prostate cancer [108].

Parthenolide is a sesquiterpene lactone used in folk medicine for its anti-inflammatory and analgesic properties. Several in vitro studies have shown that a great part of the anti-inflammatory action of this compound appears to be related to its ability to inhibit the NF- $\kappa$ B pathway. Furthermore, parthenolide has recently been reported to exert beneficial effects during endotoxic shock in rats through inhibition of NF- $\kappa$ B DNA binding in the lung [109]. Kamebakaurin (a kaurane diterpene) also prevents the activation of NF- $\kappa$ B by different stimuli in various cell types by directly targeting the DNA-binding activity of p50 [110], [111]. A novel triterpenoid, 2-cyano-3,12-dioxooleana-1,9-dien-28-oic acid inhibits NF- $\kappa \mathrm{B}$-mediated gene expression at some stage after translocation of activated NF- $\kappa$ B to the nucleus in ML-1 leukaemia cells [112].

The antioxidant compound caffeic acid phenethyl ester (CAPE), an anti-carcinogenic, anti-inflammatory and immunomodulatory substance present in Apis mellifera propolis, is also reported to prevent activation of the NF- $\kappa B$ pathway by a wide variety of inflammatory agents including TNF- $\alpha$, phorbol ester, okadaic acid and $\mathrm{H}_{2} \mathrm{O}_{2}$ [79]. The action of CAPE is selective for the NF- $\kappa B$ pathway since other transcription factors were not affected. An in vivo study has revealed that CAPE also inhibits formation of the neointima by inhibiting NF- $\kappa \mathrm{B}$ activation [79]. The mechanism by which CAPE inhibits the NF- $\kappa$ B pathway appears to be related to its ability to suppress the interaction of $\mathrm{NF}-\kappa \mathrm{B}$ with DNA, without affecting I $\kappa B$ degradation [79]. These findings further support the reported anti-inflammatory and anticancer properties of CAPE and could certainly account for the anti-inflammatory and immunomodulatory effects described for propolis extract (see for review [113]). Because NF- $\kappa$ B plays a central role in most disease processes, and since it can regulate the expression of many key genes involved in inflammatory as well as in a variety of human cancers [100], [101], [102], it represents a relevant and promising target for the development of new therapeutic agents. However, the ubiquitous nature of NF- $\kappa B$ suggests that such drugs would exhibit some undesirable side effects.

\section{Plant-Derived Constituents that Interfere with the Nitric Oxide Pathway}

Nitric oxide (NO) is synthesised by many cell types involved in immune and inflammatory responses. The principal enzyme involved is the inducible (type-2) isoform of nitric oxide synthase (NOS-2 or iNOS) which produces high-level sustained NO synthesis. Inducible NOS is expressed after stimulation by, for example, cytokines, LPS and calcium ionophore [114]. In chronic inflammation (arthritis, gastritis, inflammatory bowel disease) the inhibition of NO release is beneficial. Since nitric oxide production by iNOS occurs several steps downstream of immune stimulation, it can be regulated at many levels including transcription, translation and post-translational modification [114]. A number of medicinal plants and their isolated compounds 
have been screened for their ability to inhibit inducible NOS activity and expression.

Resveratrol (2) has been shown to suppress the iNOS expression and NO production in cultured cells by down-regulation of NF- $\kappa \mathrm{B}$ binding activity via blockade of $\mathrm{I} \kappa \mathrm{B} \alpha$ degradation [115], [116]. Structure-activity analysis of resveratrol and nine hydroxystilbenes suggests that the structural balance between oxygen functional groups on the benzene rings is important for inhibition of nitric oxide production in RAW 264.7 and J774 macrophage cells [117].

Curcumin (1) possesses anti-inflammatory activity and is a potent inhibitor of reactive oxygen species-generating enzymes such as LO/COX, xanthine dehydrogenase/oxidase and iNOS. Thus, curcumin blocks NO production and NOS activity and expression in macrophages [118] and in pancreatitis tissue of rats [10].

Recently, it has been demonstrated that silymarin reduces NO production and iNOS gene expression in macrophages, and attenuates nitric oxide production by peritoneal macrophages in LPS-treated mice, by inhibiting NFKB/Rel activation [106].

Several other phenolic compounds decrease NO production, namely, wogonin (6), baicalein (3), baicalin (4) [119], quercetin (14) [116], broussochalcone A [120], apigenin (11), luteolin (8) [121], morusin, kuwanon C, sanggenon D, bilobetin, ginkgetin, echinoisoflavanone, genistein, daidzein, glycitein, theaflavin 3,3'-digallate, and epigallocatechin 3-gallate (25) [122], [123].

Treatment with parthenolide (23) or isohelenin appears to reduce NO production and iNOS mRNA expression in cultured rat aortic smooth muscle cells treated with LPS and interferon-gamma by a mechanism involving stabilisation of the $\mathrm{I} \kappa \mathrm{B} \alpha / \mathrm{NF} \kappa \mathrm{B}$ complex [124]. Furthermore, the increase in iNOS expression caused by TPA is effectively suppressed by parthenolide in the human monocyte cell line THP-1 [124]. Other terpenes have been evaluated as inhibitors of NO production, such as yakuchinones A and B [125], celastrol (28) [126], avicins (18) (a family of triterpenoid saponins) [61], kaurane [110], prunioside [127], hypoestoxide [128], ergolide [129], costunolide [130], pimobendan [131], andrographolide [132], auranofin [133], pristimerin [134], dehydrocostus lactone [135], alpha-terpinene [136], anthraquinone [137] and furanoligularenone [57].

\section{Conclusion}

An overview of the recent literature reveals that a great number of plant-derived constituents exhibit a pleiotropic spectrum of anti-inflammatory actions. Although most, if not all of the compounds are still in the pre-clinical phase, pharmacological and molecular studies have revealed that different chemical classes of plant-derived substances show promising anti-inflammatory activity by interacting with important cellular targets, mainly by controlling the gene expression of relevant key pro-inflammatory substances involved in the genesis and maintenance of inflammation. It has become apparent that plant-derived compounds with anti-inflammatory actions represent a very active area of research. Thus, further investigation in this area may lead to the development of efficacious and safer drugs for the management of inflammatory processes, including new drugs that can prevent or delay the onset of some of the increasingly prevalent diseases of ageing such as rheumatoid arthritis, Alzheimer's disease and atherosclerosis.

\section{References}

1 Levine JD, Reichling DB. Peripheral mechanisms of inflammatory pain. In: Wall PD, Melzack R, editor. Textbook of pain; Fourth edition London: Churchill Livingstone, 1999: pp. 59-84

2 Akiyama H, Barger S, Barnum S, Bradt B, Bauer J, Cole GM, Cooper NR, Eikelenboom P, Emmerling M, Fiebich BL, Finch CE, Frautschy S, Griffin WS, Hampel H, Hull M, Landreth G, Lue L, Mrak R, Mackenzie IR, McGeer PL, O’Banion MK, Pachter J, Pasinetti G, Plata-Salaman C, Rogers J, Rydel R, Shen Y, Streit W, Strohmeyer R, Tooyoma I, Van Muiswinkel FL, Veerhuis R, Walker D, Webster S, Wegrzyniak B, Wenk G, Wyss-Coray T. Inflammation and Alzheimer's disease. Neurobiology of Ageing 2000; 21: $383-421$

3 Libby P, Ridker PM, Maseri A. Inflammation and atherosclerosis. Circulation 2002; 105: 1135-343

4 Song EK, Cho H, Kim JS, Kim NY, An NH, Kim JA, Lee SH, Kim YC. Diarylheptanoids with free radical scavenging and hepatoprotective activity in vitro from Curcuma longa. Planta Medica 2001; 67: 876-7

5 Bonte F, Noel-Hudson MS, Wepierre J, Meybeck A. Protective effect of curcuminoids on epidermal skin cells under free oxygen radical stress. Planta Medica 1997; 63: 265 -6

6 Surh YJ, Chun KS, Cha HH, Han SS, Keum YS, Park KK, Lee SS. Molecular mechanisms underlying chemopreventive activities of anti-inflammatory phytochemicals: down-regulation of COX-2 and iNOS through suppression of NF-kappa B activation. Mutation Research $2001 ; 480-481: 43-68$

7 Ammon HP, Wahl MA. Pharmacology of Curcuma longa. Planta Medica $1991 ; 57: 1-7$

8 Ramirez-Tortosa MC, Mesa MD, Aguilera MC, Quiles JL, Baro L, Ramirez-Tortosa CL, Martinez-Victoria E, Gil A. Oral administration of a turmeric extract inhibits LDL oxidation and has hypocholesterolemic effects in rabbits with experimental atherosclerosis. Atherosclerosis 1999; 147: $371-8$

9 Lim GP, Chu T, Yang F, Beech W, Frautschy SA, Cole GM. The curry spice curcumin reduces oxidative damage and amyloid pathology in an Alzheimer transgenic mouse. Journal of Neuroscience 2001; 21 : 8370-7

10 Gukovsky I, Reyes CN, Vaquero EC, Gukovskaya AS, Pandol SJ. Curcumin ameliorates ethanol and nonethanol experimental pancreatitis. American Journal of Physiology (Gastrointestinal Liver Physiology) 2003; 284: G85 - 95

11 Kim DS, Park SY, Kim JK. Curcuminoids from Curcuma longa L. (Zingiberaceae) that protect PC12 rat pheochromocytoma and normal human umbilical vein endothelial cells from betaA(1-42) insult. Neuroscience Letters 2001; 303: 57-61

12 Natarajan C, Bright JJ. Curcumin inhibits experimental allergic encephalomyelitis by blocking IL-12 signaling through Janus kinase-STAT pathway in T lymphocytes. Journal of Immunology 2002; 168: 6506 13

13 Huang MT, Lysz T, Ferraro T, Abidi TF, Laskin JD, Conney AH. Inhibitory effects of curcumin on in vitro lipoxygenase and cyclooxygenase activities in mouse epidermis. Cancer Research 1991; 51: 813-9

14 Srivastava KC, Bordia A, Verma SK. Curcumin, a major component of food spice turmeric (Curcuma longa) inhibits aggregation and alters eicosanoid metabolism in human blood platelets. Prostaglandins Leukotriene Essential Fatty Acids 1995; 52: 223 - 7

15 Zhang F, Altorki NK, Mestre JR, Subbaramaiah K, Dannenberg AJ. Curcumin inhibits cyclooxygenase-2 transcription in bile acid- and phorbol ester-treated human gastrointestinal epithelial cells. Carcinogenesis 1999; 20: $445-51$

16 Lin JK, Pan MH, Lin-Shiau SY. Recent studies on the biofunctions and biotransformations of curcumin. Biofactors 2000; 13: $153-8$

17 Jang M, Pezzuto JM. Cancer chemopreventive activity of resveratrol. Drugs Experimental Clinical Research 1999; 25: 65 - 77

18 Roemer K, Mahyar-Roemer M. The basis for the chemopreventive action of resveratrol. Drugs Today 2002; 38: 571 - 80 
19 Cheong H, Ryu SY, Kim KM. Anti-allergic action of resveratrol and related hydroxystilbenes. Planta Medica 1999; 65: 266-8

20 Bhat KPL, Kosmeder JW 2nd, Pezzuto JM. Biological effects of resveratrol. Antioxidants \& Redox Signalling 2001; 3: 1041 - 64

21 Chen T, Li J, Cao J, Xu Q, Komatsu K, Namba T. A new flavanone isolated from rhizoma Smilacis glabrae and the structural requirements of its derivatives for preventing immunological hepatocyte damage. Planta Medica 1999; 65: 56 -9

22 Rotondo S, Rajtar G, Manarini S, Celardo A, Rotillo D, de Gaetano G, Evangelista V, Cerletti C. Effect of trans-resveratrol, a natural polyphenolic compound, on human polymorphonuclear leukocyte function. British Journal of Pharmacology 1998; 123: 1691 -9

23 MacCarrone M, Lorenzon T, Guerrieri P, Agro AF. Resveratrol prevents apoptosis in K562 cells by inhibiting lipoxygenase and cyclooxygenase activity. European Journal of Biochemistry 1999 265: $27-34$

24 Jang M, Pezzuto JM. Effects of resveratrol on 12-O-tetradecanoylphorbol 13-acetate-induced oxidative events and gene expression in mouse skin. Cancer Letters 1998; 134: 81-9

25 Subbaramaiah K, Chung WJ, Michaluart P, Telang N, Tanabe T, Inoue H, Jang M, Pezzuto JM, Dannenberg AJ. Resveratrol inhibits cyclooxygenase-2 transcription and activity in phorbol ester-treated human mammary epithelial cells. The Journal of Biological Chemistry 1998; 273: $21875-82$

26 Savouret JF, Quesne M. Resveratrol and cancer: a review. Biomedical Pharmacotherapy 2002; 56: $84-7$

27 Middleton E Jr, Kandaswami C, Theoharides TC. The effects of plant flavonoids on mammalian cells: implications for inflammation, heart disease, and cancer. Pharmacololgy Review 2000; 52: 673 - 751

28 Havsteen BH. The biochemistry and medical significance of the flavonoids. Pharmacology Therapeutics 2002; 96: 67-202

29 Butenko IG, Gladtchenko SV, Galushko SV. Anti-inflammatory properties and inhibition of leukotrienes $C 4$ biosynthesis in vitro by flavonoids baicalein from Scutellaria baicalensis Georgy roots. Agents and Actions 1993; 39: C49-50

30 Hong T, Jin GB, Cho S, Cyong JC. Evaluation of the anti-inflammatory effect of baicalein on dextran sulfate sodium-induced colitis in mice. Planta Medica 2002; 68: 268 - 71

31 Lee MJ, Wang CJ, Tsai YY, Hwang JM, Lin WL, Tseng TH, Chu CY. Inhibitory effect of 12-0-tetradecanoylphorbol 13 -acetate-caused tumor promotion in benzo[a]pyrene-initiated $\mathrm{CD}-1$ mouse skin by baicalein. Nutrition Cancer 1999; 34: 185-91

32 Lin CC, Shieh DE. The anti-inflammatory activity of Scutellaria rivularis extracts and its active components, baicalin, baicalein and wogonin. American Journal of Clinical Medicine 1996; 24: 31 -6

33 Kyo R, Nakahata N, Kodama Y, Nakai Y, Kubo M, Ohizumi Y. Antagonism of saikosaponin-induced prostaglandin $\mathrm{E}_{2}$ release by baicalein in C6 rat glioma cells. Biological Pharmaceutical Bulletin 1999; 22 $1385-7$

34 You KM, Jong H-G, Kim HP. Inhibition of cyclooxygenase/lipoxygenase from human platelets by polyhydroxylated/methoxylated flavonoids isolated from medicinal plants. Archives of Pharmacological Research 1999; 22: $18-24$

35 Yoshimoto T, Furukawa M, Yamamoto S, Horie T, Watanabe-Kohno S. Flavonoids: potent inhibitors of arachidonate 5-lipoxygenase. Biochemical Biophysical Research Communication 1983; 116: 612-8

36 Ferrandiz ML, Alcaraz MJ. Anti-inflammatory activity and inhibition of arachidonic acid metabolism by flavonoids. Agents and Actions 1991; 32: $283-8$

37 Raso GM, Meli R, Di Carlo G, Pacilio M, Di Carlo R. Inhibition of inducible nitric oxide synthase and cyclooxygenase-2 expression by flavonoids in macrophage J774A.1. Life Sciences 2001; 68: 921 - 31

38 Landolfi R, Mower RL, Steiner M. Modification of platelet function and arachidonic acid metabolism by bioflavonoids. Structure-activity relations. Biochemical Pharmacology 1984; 33: 1525-30

39 Fiebrich F, Koch H. Silymarin, an inhibitor of lipoxygenase. Experientia 1979; 35: 548-60

40 Gupta OP, Sing S, Bani S, Sharma N, Malhotra S, Gupta BD, Banerjee SK, Handa SS. Anti-inflammatory and anti-arthritic activities of silymarin acting through inhibition of 5-lipoxygenase. Phytomedicine 2000; 7: $21-4$

41 De La Puerta R, Martinez E, Bravo L, Ahumada MC. Effect of silymarin on different acute inflammation models and on leukocyte migration. Journal of Pharmacy and Pharmacology 1996; 48: 968-70
42 Chen YC, Shen SC, Lee WR, Hou WC, Yang LL, Lee TJ. Inhibition of nitric oxide synthase inhibitors and lipopolysaccharide- induced inducible NOS and cyclooxygenase- 2 gene expressions by rutin, quercetin, and quercetin pentaacetate in RAW 264.7 macrophages. Journal of Cellular Biochemical 2001; 82: 537-48

43 Chi YS, Cheon BS, Kim HP. Effect of wogonin, a plant flavone from Scutellariae radix, on the suppression of cyclooxygenase-2 and the induction of inducible nitric oxide synthase in lipopolysaccharidetreated RAW264.7 cells. Biochemical Pharmacology 2000; 61: $1195-203$

44 Chen YC, Yang LL, Lee TJF. Oroxylin A inhibition of lipopolysaccharideinduced iNOS and COX-2 gene expression via suppression of nuclear factor- $\kappa B$ activation. Biochemical Pharmacology 2000; 59: 1445-57

45 Hartisch C, Kolodziej H, von Bruchhausen F. Dual inhibitory activities of tannins from Hamamelis virginiana and related polyphenols on 5lipoxygenase and lyso-PAF: acetyl-CoA acetyltransferase. Planta Medica 1997; 63: 106-10

46 Kim HK, Son KH, Chang HW, Kang SS, Kim HP. Inhibition of rat adjuvant-induced arthritis by ginkgetin, a biflavone from Ginkgo biloba leaves. Planta Medica 1999; 65: 465-7

47 Kwak WJ, Han CK, Son KH, Chang HW, Kang SS, Park BK, Kim HP. Effects of ginkgetin from Ginkgo biloba leaves on cyclooxygenases and in vivo skin inflammation. Planta Medica 2002; 68: 316-21

48 Yamaki K, Kim DH, Ryu N, Kim YP, Shin KH, Ohuchi K. Effects of naturally occurring isoflavones on prostaglandin $\mathrm{E}_{2}$ production. Planta Medica 2002; 68: $97-100$

49 Shin KH, Kim YP, Lim SS, Lee S, Ryu N, Yamada M, Ohuchi K. Inhibition of prostaglandin $E_{2}$ production by the isoflavones tectorigenin and tectoridin isolated from the rhizomes of Belamcanda chinensis. Planta Medica 1999; 65: 776-7

50 Sadik CD, Sies H, Schewe T. Inhibition of 15-lipoxygenases by flavonoids: structure-activity relations and mode of action. Biochemical Pharmacology 2003; 7549: 1 -9

51 Sala A, Recio MC, Giner RM, Manez S, Rios JL. New acetophenone glucosides isolated from extracts of Helichrysum italicum with anti-inflammatory activity. Journal of Natural Products 2001; 64: 1360-2

52 Sala A, Recio MC, Schinella GR, Manez S, Giner RM, Rios JL. A new dual inhibitor of arachidonate metabolism isolated from Helichrysum italicum. European Journal of Pharmacology 2003; 460: 219-26

53 Sala A, Recio MC, Schinella GR, Manez S, Giner RM, Cerda-Nicolas M, Rosi JL. Assessment of the anti-inflammatory activity and free radical scavenger activity of tiliroside. European Journal of Pharmacology 2003; 461: $53-61$

54 Safayhi H, Sailer ER. Anti-inflammatory actions of pentacyclic triterpenes. Planta Medica 1997; 63: 487-93

55 Fernandez MA, de las Heras B, Garcia MD, Saenz MT, Villar A. New insights into the mechanism of action of the anti-inflammatory triterpene lupeol. Journal of Pharmacy and Pharmacology 2001; 53: $1533-9$

56 Suh N, Honda T, Finlay HJ, Barchowsky A, Williams C, Benoit NE, Xie QW, Nathan C, Gribble GW, Sporn MB. Novel triterpenoids suppress inducible nitric oxide synthase (iNOS) and inducible cyclooxygenase (COX-2) in mouse macrophages. Cancer Research 1998; 58 : $717-23$

57 Hwang BY, Lee JH, Koo TH, Kim HS, Hong YS, Ro JS, Lee KS, Lee JJ. Furanoligularenone, an eremophilane from Ligularia fischeri, inhibits the LPS-induced production of nitric oxide and prostaglandin $E_{2}$ in macrophage RAW264.7 cells. Planta Medica 2002; 68: 101 - 15

58 Gupta I, Parihar A, Malhotra P, Gupta S, Ludtke R, Safayhi H, Ammon HP. Effects of gum resin of Boswellia serrata in patients with chronic colitis. Planta Medica 2000; 67: 391 -5

59 Safayhi H, Boden SE, Schweizer S, Ammon HP. Concentration-dependent potentiating and inhibitory effects of Boswellia extracts on 5-lipoxygenase product formation in stimulated PMNL. Planta Medica 2000; 66: $110-3$

60 Sailer ER, Subramanian LR, Rall B, Hoernlein RF, Ammon HP, Safayhi H. Acetyl-11-keto-beta-boswellic acid (AKBA): structure requirements for binding and 5-lipoxygenase inhibitory activity. British Journal of Pharmacology 1996; 117: 615-8

61 Haridas V, Arntzen CJ, Gutterman JU. Avicins, a family of triterpenoid saponins from Acacia victoriae (Bentham), inhibit activation of nuclear factor-kappaB by inhibiting both its nuclear localization and ability to bind DNA. Proceeding National Academy of Science (USA) 2001: 98: $11557-62$ 
62 Bermejo BP, Abad Martinez MJ, Silvan Sen AM, Sanz Gomez A, Fernandez Matellano L, Sanchez Contreras S, Diaz Lanza AM. In vivo and in vitro anti-inflammatory activity of saikosaponins. Life Sciences 1998; 63: $1147-56$

63 Bermejo Benito P, Diaz Lanza AM, Silvan Sen AM, De Santos Galindez J, Fernandez Matellano L, Sanz Gomez A, Abad Martinez MJ. Effects of some iridoids from plant origin on arachidonic acid metabolism in cellular systems. Planta Medica; 2000; 66: 324-8

64 Giner-Larza EM, Manez S, Giner RM, Recio MC, Prieto JM, Cerda-Nicolas M, Rios JL. Anti-inflammatory triterpenes from Pistacia terebinthus galls. Planta Medica 2002; 68: $311-5$

65 Kim YP, Lee EB, Kim SY, Li D, Ban HS, Lim SS, Shin KH, Ohuchi K. Inhibition of prostaglandin $\mathrm{E} 2$ production by platycodin $\mathrm{D}$ isolated from the root of Platycodon grandiflorum. Planta Medica 2001; 67: 362 -4

66 Diaz Lanza AM, Abad Martinez MJ, Fernandez Matellano L, Recuero Carretero C, Villaescusa Castillo L, Silvan Sen AM, Bermejo Benito P. Lignan and phenylpropanoid glycosides from Phillyrea latifolia and their in vitro anti-inflammatory activity. Planta Medica 2001; 67: 219-23

67 Prieto JM, Giner RM, Recio Mf MC, Schinella G, Manez S, Rios JL. Diphyllin acetylapioside, a 5-lipoxygenase inhibitor from Haplophyllum hispanicum. Planta Medica 2002; 68: 359-60

68 Ringbom T, Segura L, Noreen Y, Perera P, Bohlin L. Ursolic acid from Plantago major, a selective inhibitor of cyclooxygenase-2 catalyzed prostaglandin biosynthesis. Journal of Natural Products 1998; 61 $1212-5$

69 Manez S, Recio MC, Giner RM, Rios JL. Effect of selected triterpenoids on chronic dermal inflammation. European Journal of Pharmacology 1997; 334: $103-5$

70 Liu J. Pharmacology of oleanolic acid and ursolic acid. Journal of Ethnopharmacology 1995; 49: 57-68

71 Subbaramaiah K, Michaluart P, Sporn MB, Dannenberg AJ. Ursolic acid inhibits cyclooxygenase-2 transcription in human mammary epithelial cells. Cancer Research 2000; 60: 2399-404

72 Suh N, Wang Y, Honda T, Gribble GW, Dmitrovsky E, Hickey WF, Maue RA, Place AE, Porter DM, Spinella MJ, Williams CR, Wu G, Dannenberg AJ, Flanders KC, Letterio JJ, Mangelsdorf DJ, Nathan CF, Nguyen L, Porter WW, Ren RF, Roberts AB, Roche NS, Subbaramaiah K, Sporn MB. A novel synthetic oleanane triterpenoid, 2-cyano-3,12-dioxoolean-1,9dien-28-oic acid, with potent differentiating, antiproliferative, and anti-inflammatory activity. Cancer Research 1999; 59: 336-41

73 Hong CH, Noh MS, Lee WY, Lee SK. Inhibitory effects of natural sesquiterpenoids isolated from the rhizomes of Curcuma zedoaria on prostaglandin $\mathrm{E}_{2}$ and nitric oxide production. Planta Medica 2002; 68: $545-7$

74 Hernandez V, del Carmen Recio M, Manez S, Prieto JM, Giner RM, Rios JL. A mechanistic approach to the in vivo anti-inflammatory activity of sesquiterpenoid compounds isolated from Inula viscosa. Planta Medica 2001; 67: 726-1

75 Rosas-Romero A, Manchado CM, Crescente O, Acosta M, Curini M, Epifano F, Marcotullio MC, Rosati O, Tubaro A, Sosa S. Anti-inflammatory sesquiterpene lactones from Lourteigia ballotaefolia. Planta Medica 2002; 68: $843-5$

76 Suksamrarn A, Kumpun S, Kirtikara K, Yingyongnarongkul B, Suksamrarn S. Iridoids with anti-inflammatory activity from Vitex peduncularis. Planta Medica 2002; 68: 72 -3

77 Ringbom T, Huss U, Stenholm A, Flock S, Skattebol L, Perera P, Bohlin L. COX-2 inhibitory effects of naturally occurring and modified fatty acids. Journal of Natural Products 2001; 64: 745-9

78 Michaluart P, Masferrer JL, Carothers AM, Subbaramaiah K, Zweife BS, Koboldt C, Mestre JR, Grunberger D, Sacks PG, Tanabe T, Dannenberg AJ. Inhibitory effects of caffeic acid phenethyl ester on the activity and expression of cyclooxygenase-2 in human oral epithelial cells and in a rat model of inflammation. Cancer Research 1999; 59 2347-52

79 Maffia P, Ianaro A, Pisano B, Borrelli F, Capasso F, Pinto A, Ialenti A. Beneficial effects of caffeic acid phenethyl ester in a rat model of vascular injury. British Journal of Pharmacology 2002; 136: 353-60

80 Muschietti L, Gorzalczany S, Ferraro G, Acevedo C, Martino V. Phenolic compounds with anti-inflammatory activity from Eupatorium buniifolium. Planta Medica 2001; 67: 43-4

81 Resch M, Heilmann J, Steigel A, Bauer R. Further phenols and polyacetylenes from the rhizomes of Atractylodes lancea and their anti-inflammatory activity. Planta Medica 2001; 67: 437-42
82 Danz H, Stoyanova S, Thomet OA, Simon HU, Dannhardt G, Ulbrich H, Hamburger M. Inhibitory activity of tryptanthrin on prostaglandin and leukotriene synthesis. Planta Medica 2002; 68: 875-80

83 Woo HG, Lee CH, Noh MS, Lee JJ, Jung YS, Baik EJ, Moon CH, Lee SH. Rutaecarpine, a quinazolinocarboline alkaloid, inhibits prostaglandin production in RAW264.7 macrophages. Planta Medica 2001; 67: $505-9$

84 Moon TC, Murakami M, Kudo I, Son KH, Kim HP, Kang SS, Chang HW. A new class of COX-2 inhibitor, rutaecarpine from Evodia rutaecarpa. Inflammation Research 1999; 48: 621 -5

85 Sheu JR, Kan YC, Hung WC, Su CH, Lin CH, Lee YM, Yen MH. The antiplatelet activity of rutaecarpine, an alkaloid isolated from Evodia rutaecarpa, is mediated through inhibition of phospholipase C. Thrombosis Research 1998; 92: 53-64

86 Sheu JR, Hung WC, Wu CH, Lee YM, Yen MH. Antithrombotic effect of rutaecarpine, an alkaloid isolated from Evodia rutaecarpa, on platelet plug formation in in vivo experiments. British Journal of Haematology 2000; 110: $110-5$

87 Wang GJ, Wu XC, Chen CF, Lin LC, Huang YT, Shan J, Pang PKT. Vasorelaxing action of rutaecarpine: Effects of rutaecarpine on calcium channel activities in vascular endothelial and smooth muscle cells. The Journal of Pharmacology and Experimental Therapeutics 1999; 289: $1237-44$

88 Kobayashi Y, Hoshikuma K, Nakano Y, Yokoo Y, Kamiya T. The positive inotropic and chronotropic effects of evodiamine and rutaecarpine, indoloquinazoline alkaloids isolated from the fruits of Evodia rutaecarpa, on the guinea-pig isolated right atria: possible involvement of vanilloid receptors. Planta Medica 2001; 67: 244-8

$89 \mathrm{Hu}$ CP, Xiao L, Deng HW, Li YJ. The cardioprotection of rutaecarpine is mediated by endogenous calcitonin related-gene peptide through activation of vanilloid receptors in guinea-pig hearts. Planta Medica 2002; 68: 705-9

$90 \mathrm{Hu}$ CP, Xiao L, Deng HW, Li YJ. The depressor and vasodilator effects of rutaecarpine are mediated by calcitonin gene-related peptide. Planta Medica 2003; 69: 125 -9

91 Hu CP, Li NS, Xiao L, Deng HW, Li YJ. Involvement of capsaicin-sensitive sensory nerves in cardioprotection of rutaecarpine in rats. Regulatory Peptides 2003; 114: 45 -9

92 Wang CC, Huang YJ, Chen LG, Lee LT, Yang LL. Inducible nitric oxide synthase inhibitors of Chinese herbs III. Rheum palmatum. Planta Medica 2002; 68: 869-74

93 Klaas CA, Wagner G, Laufer S, Sosa S, Della Loggia R, Bomme U, Pahl HL, Merfort I. Studies on the anti-inflammatory activity of phytopharmaceuticals prepared from Arnica flowers. Planta Medica 2002; 68: $385-91$

94 Hofbauer R, Frass M, Gmeiner B, Kaye AD, Frost EA. Effects of garlic extract (Allium sativum) on neutrophil migration at the cellular level. Heart Disease 2001; 3: $14-7$

95 Segura L, Freixa B, Ringbom T, Vila R, Perera P, Adzet T, Bohlin L, Canigueral S. Anti-inflammatory activity of dichloromethane extract of Heterotheca inuloides in vivo and in vitro. Planta Medica 2000; 66: $553-5$

96 Cho CH, Mei QB, Shang P, Lee SS, So HL, Guo X, Li Y. Study of the gastrointestinal protective effects of polysaccharides from Angelica sinensis in rats. Planta Medica 2000; 66: 48-51

97 Tang HQ Hu J, Yang L, Tan RX. Terpenoids and flavonoids from Artemisia species. Planta Medica 2000; 66: 391 -3

98 Borchers AT, Keen CL, Stern JS, Gershwin ME. Inflammation and Native American medicine: the role of botanicals. American Journal Clinical Nutrition 2000; 72: 339-47

99 Barnes PJ, Karin M. Nuclear factor-kappaB: a pivotal transcription factor in chronic inflammatory diseases. New England Journal of Medicine 1997; 336: $1066-71$

${ }^{100}$ Ghosh S, Karin M. Missing pieces in the NF-kappaB puzzle. Cell. 2002; 109 Suppl : S81-96

101 Bremner P, Heinrich M. Natural products as targeted modulators of the nuclear factor-kappaB pathway. Journal of Pharmacy and Pharmacology 2002; 54: 453-72

${ }^{102}$ Haefner B. NF-kappaB: arresting a major culprit in cancer. Drug Discovery Today 2002; $15: 653-63$

${ }^{103}$ Jobin C, Bradham CA, Russo MP, Juma B, Narula AS, Brenner DA, Sartor RB. Curcumin blocks cytokine-mediated NF- $\kappa$ B activation and proinflammatory gene expression by inhibiting inhibitory factor I- $\kappa \mathrm{B}$ kinase activity. The Journal of Immunology 1999; 163: $3474-83$ 
${ }^{104}$ Pan MH, Lin-Shiau SY, Lin JK. Comparative studies on the suppression of nitric oxide synthase by curcumin and its hydrogenated metabolites through down-regulation of I $\kappa \mathrm{B}$ kinase and NFKB activation in macrophages. Biochemical Pharmacology 2000; 60: 1665 76

105 Ukil A, Maity S, Karmakar S, Datta N, Vedasiromoni JR, Das PK. Curcumin, the major component of food flavour turmeric, reduces mucosal injury in trinitrobenzenesulphonic acid-induced colitis. British Journal of Pharmacology 2003; 139: 209-18

106 Kang JS, Jeon YJ, Kim HM, Han SH, Yang KH. Inhibition of inducible nitric-oxide synthase expression by silymarin in lipopolysaccharidestimulated macrophages. The Journal of Pharmacology and Experimental Therapeutic 2002; 302: $138-44$

107 Dhanalakshmi S, Singh RP, Agarwal C, Agarwal R. Silibinin inhibits constitutive and TNFalpha-induced activation of NF-kappaB and sensitizes human prostate carcinoma DU145 cells to TNFalpha-induced apoptosis. Oncogene 2002; 21: 1759-67

108 Gupta S, Afaq F, Mukhtar H. Involvement of nuclear factor-kappa B, Bax and Bcl-2 in induction of cell cycle arrest and apoptosis by apigenin in human prostate carcinoma cells. Oncogene 2002; 21 : $3727-38$

109 Sheehan M, Wong HR, Hake PW, Malhotra V, O'Connor M, Zingarelli B. Parthenolide, an inhibitor of the nuclear factor-kappaB pathway, ameliorates cardiovascular derangement and outcome in endotoxic shock in rodents. Molecular Pharmacology 2002; 61: 953-63

${ }^{110}$ Hwang BY, Lee JH, Koo TH, Kim HS, Hong YS, Ro JS, Lee KS, Lee JJ. Kaurane diterpenes from Isodon japonicus inhibit nitric oxide and prostaglandin $\mathrm{E}_{2}$ production and NF-kappaB activation in LPS-stimulated macrophage RAW264.7 cells. Planta Medica 2001; 67: 406 10

111 Lee JH, Koo TH, Hwang BY, Lee JJ. Kaurane diterpene, kamebakaurin, inhibits NF-kappa B by directly targeting the DNA-binding activity of p50 and blocks the expression of antiapoptotic NF-kappa B target genes. Journal of Biological Chemistry 2002; 277: 18411 20

112 Stadheim TA, Suh N, Ganju N, Sporn MB, Eastman A. The novel triterpenoid 2-cyano-3,12-dioxooleana-1,9-dien-28-oic acid (CDDO) potently enhances apoptosis induced by tumor necrosis factor in human leukemia cells. Journal of Biological Chemistry 2002; 277: $16448-55$

113 Burdock GA. Review of the biological properties and toxicity of bee propolis (propolis). Food Chemical Toxicology 1998; 36: 347-63

114 Weinberg JB. Nitric oxide synthase 2 and cyclooxygenase 2 interactions in inflammation. Immunology Research 2000; 22: 319-41

115 Tsai SH, Lin-Shiau SY, Lin JK. Suppression of nitric oxide synthase and the down-regulation of the activation of NFkappaB in macrophages by resveratrol. British Journal of Pharmacology 1999; 126 $673-80$

116 Chan MM, Mattiacci JA, Hwang HS, Shah A, Fong D. Synergy between ethanol and grape polyphenols, quercetin, and resveratrol, in the inhibition of the inducible nitric oxide synthase pathway. Biochemical Pharmacology 2000; 60: 1539-48

117 Cho D, Koo N, Chung W, Kim T, Ryu S, Im S, Kim K. Effects of resveratrol-related hydroxystilbenes on the nitric oxide production in macrophage cells: structural requirements and mechanism of action. Life Science 2002; 71: 2071

118 Chan MM, Huang HI, Fenton MR, Fong D. In vivo inhibition of nitric oxide synthase gene expression by curcumin, a cancer preventive natural product with anti-inflammatory properties. Biochemical Pharmacology 1998; 55: 1955-62

119 Chen Y-C, Shen S-C, Chen L-G, Lee T J-F, Yang L-L. Wogonin, baicalin, and baicalein inhibition of inducible nitric oxide synthase and cyclooxygenase-2 gene expressions induced by nitric oxide synthase inhibitors and lipopolysaccharide. Biochemical Pharmacology 2001; 61: $1417-27$

120 Cheng Z, Lin C, Hwang T, Teng C. Broussochalcone A, a potent antioxidant and effective suppressor of inducible nitric oxide synthase in lipopolysaccharide-activated macrophages. Biochemical Pharmacology 2001; 61: 939-46
${ }^{121}$ Kim HK, Cheon BS, Kim YH, Kim SY, Kim HP. Effects of naturally occurring flavonoids on nitric oxide production in the macrophage cell line RAW 264.7 and their structure-activity relationships. Biochemical Pharmacology 1999; 58: 759-65

122 Cheon BS, Kim YH, Son KS, Chang HW, Kang SS, Kim HP. Effects of prenylated flavonoids and biflavonoids on lipopolysaccharide-induced nitric oxide production from the mouse macrophage cell line RAW 264.7. Planta Medica 2000; 66: 596-600

123 Sheu F, Lai HH, Yen GC. Suppression effect of soy isoflavones on nitric oxide production in RAW 264.7 macrophages. Journal of Agriculture Food Chemistry 2001; 49: 1767-72

${ }^{124}$ Fukuda K, Hibiya Y, Mutoh M, Ohno Y, Yamashita K, Akao S, Fujiwara $\mathrm{H}$. Inhibition by parthenolide of phorbol ester-induced transcriptional activation of inducible nitric oxide synthase gene in a human monocyte cell line THP-1. Biochemical Pharmacology 2000; 60: $595-600$

${ }^{125}$ Chun KS, Kang JY, Kim OH, Kang H, Surh YJ. Effects of yakuchinone A and yakuchinone $\mathrm{B}$ on the phorbol ester-induced expression of COX-2 and iNOS and activation of NF-kappaB in mouse skin. Journal of Environmental Pathology Toxicology and Oncology 2002; 21: 131 -9

${ }^{126}$ Allison AC, Cacabelos R, Lombardi VRM, Álvarez XA, Vigo C. Celastrol, a potent antioxidant and anti-inflammatory drug, as a possible treatment for Alzheimer's disease. Progress in Neuro-Psychopharmacology \& Biological Psychiatry 2001; 25: $1341-57$

127 Oh H, Oh GS, Seo WG, Pae HO, Chai KY, Kwon TO, Lee YH, Chung HT, Lee HS. Prunioside A: a new terpene glycoside from Spiraea prunifolia. Journal of Natural Products 2001; 64: 942 - 4

${ }^{128}$ Ojo-Amaize EA, Kapahi P, Kakkanaiah VN, Takahashi T, Shalom-Barak T, Cottam HB, Adesomoju AA, Nchekwube EJ, Oyemade OA, Karin M, Okogun JI. Hypoestoxide, a novel anti-inflammatory natural diterpene, inhibits the activity of IkappaB kinase. Cellular Immunology 2001; 209: 149-57

${ }^{129}$ Whan Han J, Gon Lee B, Kee Kim Y, Woo Yoon J, Kyoung Jin H, Hong S, Young Lee H, Ro Lee K, Woo Lee H. Ergolide, sesquiterpene lactone from Inula britannica, inhibits inducible nitric oxide synthase and cyclo-oxygenase-2 expression in RAW 264.7 macrophages through the inactivation of NF-kappaB. British Journal of Pharmacology 2001; 133: $503-12$

${ }^{130} \mathrm{Koo}$ TH, Lee JH, Park YJ, Hong YS, Kim HS, Kim KW, Lee JJ. A sesquiterpene lactone, costunolide, from Magnolia grandiflora inhibits NFkappa B by targeting I kappa B phosphorylation. Planta Medica 2001; 67: $103-7$

${ }^{131}$ Matsumori A, Nunokawa Y, Sasayama S. Pimobendan inhibits the activation of transcription factor NF-kappaB: a mechanism which explains its inhibition of cytokine production and inducible nitric oxide synthase. Life Science 2000; 67: 2513-9

132 Chiou WF, Chen CF, Lin JJ. Mechanisms of suppression of inducible nitric oxide synthase (iNOS) expression in RAW 264.7 cells by andrographolide. British Journal of Pharmacology 2000; 129: 1553-60

133 Yamashita M, Ichinowatari G, Yamaki K, Ohuchi K. Inhibition by auranofin of the production of prostaglandin $\mathrm{E}_{2}$ and nitric oxide in rat peritoneal macrophages. European Journal of Pharmacology 1999; 368: $251-8$

${ }^{134}$ Dirsch VM, Kiemer AK, Wagner H, Vollmar AM. The triterpenoid quinonemethide pristimerin inhibits induction of inducible nitric oxide synthase in murine macrophages. European Journal of Pharmacology 1997; 336: $211-7$

135 Lee HJ, Kim NY, Jang MK, Son HJ, Kim KM, Sohn DH, Lee SH, Ryu JH. A sesquiterpene, dehydrocostus lactone, inhibits the expression of inducible nitric oxide synthase and TNF-alpha in LPS-activated macrophages. Planta Medica 1999; 65: 104-8

136 Lim SS, Shin KH, Ban HS, Kim YP, Jung SH, Kim YJ, Ohuchi K. Effect of the essential oil from the flowers of Magnolia sielboldii on lipopolysaccharide-induced production of nitric oxide and prostaglandin $E_{2}$ by rat peritoneal macrophages. Planta Medica 2002; 68: 459-62

137 Wang CC, Huang YJ, Chen LG, Lee LT, Yang LL. Inducible nitric oxide synthase inhibitors of Chinese herbs III. Rheum palmatum. Planta Medica 2002; 68: 869-74 